\title{
Shade tree timber as a source of income diversification in agroforestry coffee plantations, Peru
}

Lenka EHRENBERGEROVÁ

Zuzana ŠEPTUNOVÁ ${ }^{1}$

Hana HABRovÁ ${ }^{1}$

Ronald Hugo PuerTA TUESTA ${ }^{2}$

Radim MATULA ${ }^{1}$

${ }^{1}$ Mendel University in Brno

Zemědělská 3

Brno 61300

Czech Republic

2 Universidad Nacional Agraria de la Selva Avenida Universitaria km 1.5

Tingo María

Peru

\section{Auteur correspondant /}

Corresponding author:

Lenka Ehrenbergerová -

lenka.ehrenbergerova@mendelu.cz
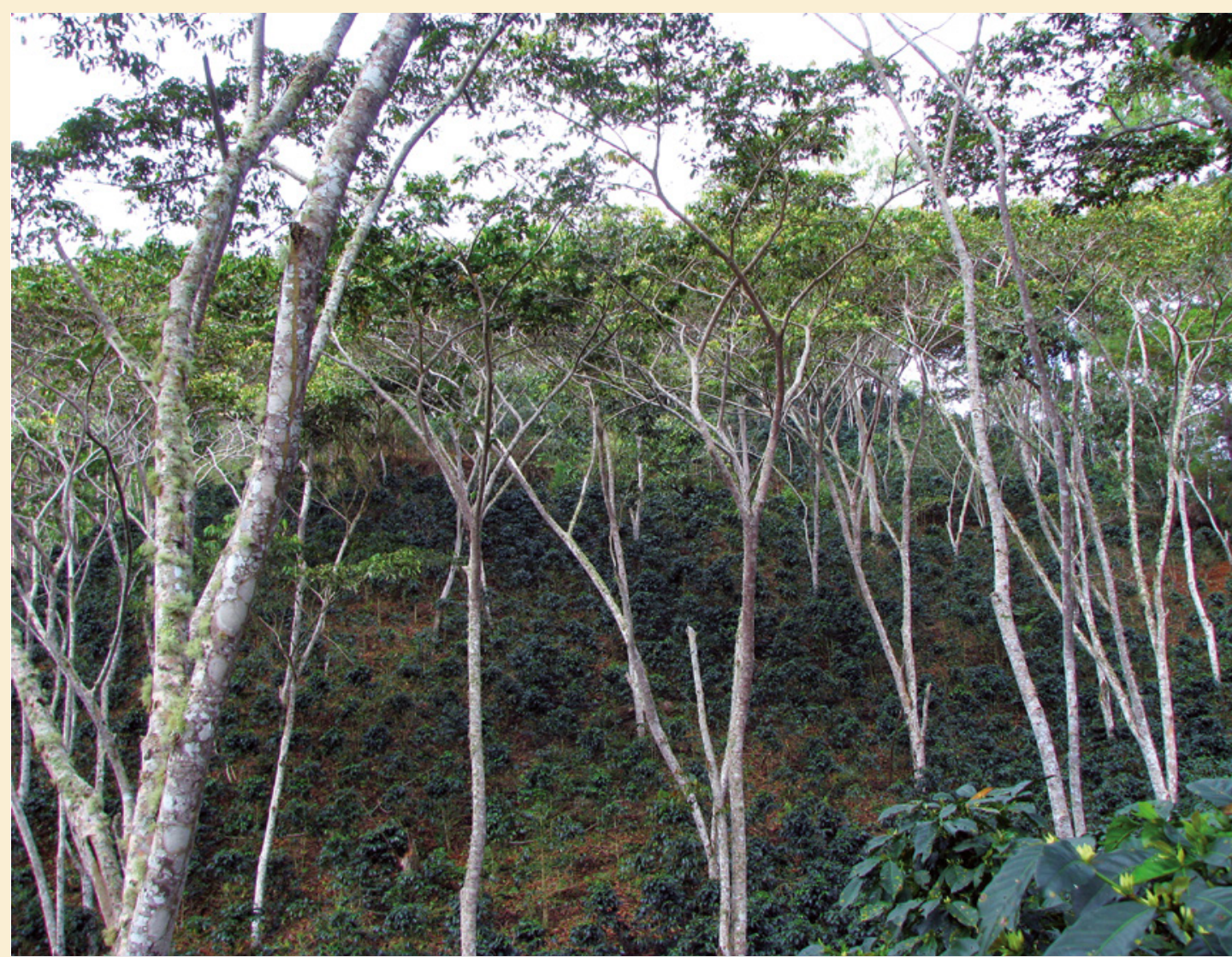

Photo 1.

Ave Fenix coffee plantation, which is dominantly shaded by Inga spp. trees.

Photo L. Ehrenbergerová.

Doi : 10.19182/bft2019.342.a31812 - Droit d'auteur (c) 2019, Bois et Forêts des Tropiques (c) Cirad - Date de soumission : 3 septembre 2018 ; date d'acceptation : 3 avril 2019 ; date de publication : 15 novembre 2019.

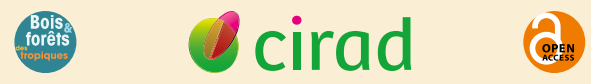

(c) $(1) \Theta$
Licence Creative Commons :

Attribution - Pas de Modification 4.0 International.

Attribution-NoDerivatives 4.0 International (CC BY-ND 4.0)
Citer l'article / To cite the article

Ehrenbergerová L., Šeptunová Z., Habrová H., Puerta Tuesta R. H., Matula R., 2019. Shade tree timber as a source of income diversification in agroforestry coffee plantations, Peru. Bois et Forêts des Tropiques, 342: 93-103. Doi : https://doi.org/10.19182/bft2019.342.a31812 


\section{RÉSUMÉ}

\section{Le bois d'ombrage comme source de diversification des revenus dans les plantations de café agroforestières au Pérou}

Le café est traditionnellement cultivé dans les systèmes agroforestiers. Les arbres d'ombrage dans les plantations de café fournissent d'importants services écosystémiques, et leur bois peut également être une bonne source de revenus pour les caféiculteurs. Toutefois, on manque d'informations essentielles sur la valeur du bois d'ombrage et sa contribution potentielle au revenu des caféiculteurs, fondées sur des données empiriques. Le revenu que l'on pouvait tirer des arbres d'ombrage a été estimé pour trois plantations de café avec différentes essences d'arbres d'ombrage. Pour estimer le volume de bois commercialisable des arbres sur pied, des équations allométriques ont été élaborées. D'une part, nos résultats ont montré que la valeur du bois des arbres d'ombrage variait considérablement. Elle représentait seulement 2 à $3 \%$ du revenu annuel de la ferme lorsque la plantation était dominée par l'espèce native Inga spp. D'autre part, la plantation principalement ombragée par des Eucalyptus présentait un potentiel élevé tant annuel (50-68 \% du revenu de la plantation) que total pour la valeur du bois (92-96 \% du revenu), suivie par la plantation ombragée principalement par des Pinus (32-49\% du revenu de la plantation pour le volume annuel de bois et $89-94 \%$ du revenu de la plantation pour le volume total de bois). Il est évident que les arbres d'ombrage peuvent constituer une bonne réserve économique pour les caféiculteurs lorsque des espèces exotiques d'Eucalyptus ou de Pinus sont plantées. Cependant, à l'aide de données sur des arbres individuels, on a découvert que l'arbre d'ombrage indigène relativement rare Retrophyllum rospigliosii, que l'on trouvait dans presque toutes les plantations, a une grande valeur ligneuse et fournit une grande quantité de bois, ce qui en fait une espèce d'ombre à fort potentiel agroforestier.

Mots-clés : Eucalyptus, Inga, Pinus, Retrophyllum rospigliosii,équation allométrique, système agroforestier, plantation de café, revenu agricole, Pérou.

\section{ABSTRACT}

\section{Shade tree timber as a source of income diversification in agroforestry coffee plantations, Peru}

Coffee is traditionally grown in agroforestry systems. Shade trees in coffee plantations provide important ecosystem services, and their timber may also be a good source of income for coffee growers. However, key information on the value of shade tree timber and its potential contribution to the income of coffee growers based on empirical data is lacking. The income that could be obtained from shade trees was estimated for three coffee plantations with different shade tree species. To estimate the marketable timber volume of standing trees, allometric equations were developed. Our results showed that the value of the shade tree timber varied significantly. It represented only $2-3 \%$ of the annual coffee farm income on the coffee plantation dominated by native Inga spp. On the other hand, the plantation predominantly shaded by Eucalyptus trees had high potential annual (50-68\% of plantation income) and total (92-96\% of plantation income) timber value, followed by the plantation shaded predominantly by Pinus (32-49\% of plantation income for annual timber volume and $89-94 \%$ of plantation income for total timber volume). It is evident that shade trees may be a good economic reserve for coffee growers when exotic Eucalyptus or Pinus tree species are planted. However, using individual-tree data, it was found that the relatively rare native shade tree Retrophyllum rospigliosii, which was found in almost all plantations, has a high timber value and a large timber supply, making it a shade species with high potential for agroforestry.

Keywords: Eucalyptus, Inga, Pinus, Retrophyllum rospigliosii, allometric equation, agroforestry system, coffee plantation, farm income, Peru.

\section{La madera de árboles de sombra como fuente de diversificación de los ingresos en las plantaciones agroforestales de café de Perús}

El café se cultiva tradicionalmente en sistemas agroforestales. Los árboles de sombra en las plantaciones de café proporcionan importantes servicios ecosistémicos, y su madera puede asimismo ser una buena fuente de ingresos para los caficultores. Sin embargo, nos falta información esencial, basada en datos empíricos, sobre el valor de la madera de sombra y su potencial contribución a los ingresos de los caficultores. Se han estimado los ingresos que se podían obtener de los árboles de sombra para tres plantaciones de café con diferentes especies de árboles de sombra. Se han elaborado ecuaciones alométricas para estimar el volumen de madera que se puede comercializar de los árboles en pie. Por un lado, los resultados mostraron que el valor de la madera de los árboles de sombra variaba considerablemente. Ello representaba solamente del 2 al $3 \%$ de los ingresos anuales de la explotación, con la producción de café dominada por Inga spp. nativas. Por otro lado, la plantación con la sombra principalmente de Eucalyptus tenía un potencial anual (50-68\% de los ingresos de la plantación) y un valor total de la madera $(92-96 \%$ de los ingresos de la plantación) elevados, seguida por la plantación con sombra principalmente de Pinus (32-49\% de los ingresos de la plantación para el volumen anual de madera y 89-94 \% de los ingresos de la plantación para el volumen total de madera). Es evidente que los árboles de sombra pueden constituir una buena reserva económica para los caficultores cuando se plantan especies exóticas de Eucalyptus o de Pinus. Sin embargo, con la ayuda de datos sobre árboles individuales, se descubrió que el árbol de sombra indígena relativamente raro Retrophyllum rospigliosii, que se encontraba en casi todas las plantaciones, tiene un gran valor leñoso y una gran cantidad de madera, lo que lo convierte en una especie de sombra con gran potencial agroforestal.

Palabras clave: Eucalyptus, Inga, Pinus, Retrophyllum rospigliosii, ecuación alométrica, sistema agroforestal, plantación de café, ingresos agrícolas, Perú. 


\section{Introduction}

Agroforestry is widely considered as a potential way of improving socioeconomic and environmental sustainability in developing countries (Jiménez-Avila and Martınez, 1979; Barradas and Fanjul, 1984; Beer, 1987; Garrett et al., 2000; Alavalapati and Nair, 2001; Nair, 2002). Shade trees in agroforestry systems could serve as a source of wood and firewood (Rice, 2008). This contributes to the growing demand for wood products in domestic markets of developing countries, it may offer significant economic opportunities for small-scale agroforestry producers (Scherr, 2004) and it also helps to reduce emissions from deforestation and forest degradation (REDD) (Horowitz, 2016). Besides the wood and firewood, shade trees provide a variety of products, such as fibre, food, and medicinal products, oils and gums, and play a critical role in meeting the basic needs of the local population (Nair, 1993). Agroforestry systems also have non-productive functions, including providing a refuge for forest biota (Perfecto et al., 1996), reducing pressure for further forest conversion to agriculture (Noponen et al., 2013), stabilizing microclimatic conditions (Lin, 2007; Siles, 2010) and protecting the soil (Wintgens, 2004).

Coffee is one of the key traded commodities for developing countries (ICO, 2003), and its cultivation in agroforestry systems represents the potential to diversify production and thereby, income of farmers (Rice, 2008). Coffee prices in the international market are highly unstable, which causes socio-economic problems for local coffee growers (Daviron and Ponte, 2005; ICO, 2003). Coffee is the primary agro-exportation product in Peru and positions this country among the world's largest coffee producers (Méndez et al., 2015). Coffee was grown on 55,174 hectares with production of 41,438 tonnes of parchment coffee in 2017 (Ministerio de Agricultura y Riego, 2017) exported mainly to the United States, Germany, Belgium, Canada, Sweden and South Korea (Díaz Vargas and Willems, 2017). Approximately 63\% of Peruvian coffee plantations are owned by small-scale farmers, and the average size of a farm is less than 10 ha (Cuadras, 2006). Low coffee prices at which production costs exceed income are an ongoing problem for Peruvian coffee growers (Díaz Vargas and Willems, 2017; JNC, 2018 and personal communication with coffee growers in Villa Rica) (see figure 1). Coffee plantations certified by the Rainforest Alliance, in which the income from coffee beans is higher than production costs, are the exception (Barham and Weber, 2012).

For example, in coffee agroforestry systems in the department of San Martin, Peru, net income ranged from 1,480 to $4,303 € /$ ha/y Jezeer et al., 2018). However, the increase in net cash returns for coffee farmers is driven more by coffee bean yields than premium prices (Barham and Weber, 2012); coffee yields in Peru- vian coffee plantations have been significantly affected by the outbreak of coffee leaf rust in recent years (Avelino et al., 2015), declining by half on average (Nelson et al., 2016). This decline in coffee yield means that coffee growers increasingly rely on income from non-coffee products, of which the timber from shade trees plays an important role (Jezeer et al., 2018).

The most common tree species used for shading in coffee plantations in Peru are leguminous trees of Inga spp. (Rice, 2008) but there are a number of other native tree species used for this purpose (Greenberg and Rice, 1999). In recent decades, farmers have started to plant exotic Pinus spp. and Eucalyptus spp.

Tropical agroforestry systems have been proposed as farming systems that can reconcile economic and environmental goals (Schroth et al., 2004; Steffan-Dewenter et al., 2007). However, changing prices on global coffee markets and increased incidence of pest and disease are putting pressure on smallholder coffee farmers. Moreover, climate change is expected to even exacerbate their vulnerability (Morton, 2007). Timber from shade trees may serve as an additional income for local coffee producers and may help to offset the fluctuation in farm income due to varying coffee production and prices. The value of shade tree timber is considerable because it serves as a constant and free source of construction material as well as an economic reserve (Peeters et al., 2003). Based on questionnaire survey, Rice (2008) assumed that in Peruvian smallholder coffee plantations, $28.5 \pm 1.87 \%$ of the total income originated from shade-derived sources, and in Guatemalan plantations, shade-derived income represented $18.77 \pm 2.08 \%$ of the total value. However, an evaluation of the extent to which timber production contributes to the economy of coffee producers based on field measurement is still lacking. To estimate the potential timber value in the coffee plantations, allometric equations, which can be used to easily calculate the timber volume of standing shade trees, are crucial but are generally lacking. Generalized biomass prediction equations have been devel- 
oped for tropical species (Chave et al., 2005), but the majority of equations serve to calculate total tree biomass mainly for carbon storage estimation; therefore, they cannot be used to calculate the volume of marketable timber.

Economic considerations are among the most important factors that determine the ultimate value and feasibility of agroforestry for the land user. However, information on shade tree timber production and its economic value, the key aspects of agroforestry systems, is still lacking (Nair, 1993). Therefore, the main goal of this paper was to estimate the timber value of shade trees and the extent to which the income from the shade tree timber may contribute to the economy of coffee producers. Specifically, we aimed to estimate wood volumes and the annual wood production of the shade trees and to recalculate these timber volumes as the real economic value that farmers were able to realize in local markets. In addition, to assess the timber volume of standing trees, we developed allometric equations for the selected shade tree species (Pinus spp., Eucalyptus spp. and Retrophyllum rospigliosii Pilg. C.N. Page) based on easily measurable stem diameter, which can provide a quick but four coffee plantations dominantly shaded by Inga spp. (Inga edulis C. Marius., I. densiflora Bentham, I. adenophylla Pittier, I. feuillei DC., and I. velutina Willd.) (hereinafter Inga) and exotic Eucalyptus spp. (E. saligna Sm. and E. grandis W. Hill) (hereinafter Eucalyptus) and Pinus spp. ( $P$. oocarpa Schiede and $P$. tecunumanii Eguiluz and J.P. Perry) (hereinafter Pinus). Inga trees are very commonly found throughout Latin America, used as the principal shade tree species in agroforestry systems. We also included Retrophyllum rospigliosii (hereinafter Retrophyllum) in the studied species because it is a common native shade tree used mainly on the boundaries of coffee plantations whose timber sells for the same price local market. precise estimation of shade tree timber. We used data from as or even a higher price than that of exotic species on the

\section{Materials and methods}

\section{Study area description}

This study was conducted in the Villa Rica district, Oxapampa province, Pasco region, Peru. The average altitude in this district is $1,467 \mathrm{~m}$ a.s.l. The average annual rainfall and temperature are $1,590 \mathrm{~mm}$ and $17.8^{\circ} \mathrm{C}$ in this tropical humid mountain forest zone (Ponce Gonzáles, 2008). The soils, which are classified as dystric Cambisols (Brack and Mendiola Vargas, 2012; Michéli et al., 2006), have low structural stability. The Villa Rica district is one of the most important coffee production areas in Peru. The main economic activity in this district is agriculture, mostly shaded coffee plantations and some cattle farming.

Three coffee agroforestry plantations with different dominant shade tree species were selected near Villa Rica town: Avé Fénix (Inga site), Santa Rosa (Pinus site) and La Torre (Eucalyptus site). All these plantations had shade trees of felling age. The summary of the characteristics and locations of the studied plantations are shown in table I and figure 2. Detailed descriptions of the studied coffee plantations are provided in annex 1.

The upper $30 \mathrm{~cm}$ of soil at all study sites was classified as loam, with low $\mathrm{pH}$ and high soil carbon. All plantations were growing the first generation of shaded coffee after conversion from pastureland, and the shade trees were planted at the same time as the coffee shrubs. The coffee plantation management was relatively simple and applied identically across all coffee plantations: coffee was pruned regularly in a systematic way at a height of 0.3-0.5 m, and the organic material from the pruning was left between the coffee rows. All plantations were certified as organic with similar management and inputs.

The microclimate of the Inga site was measured during

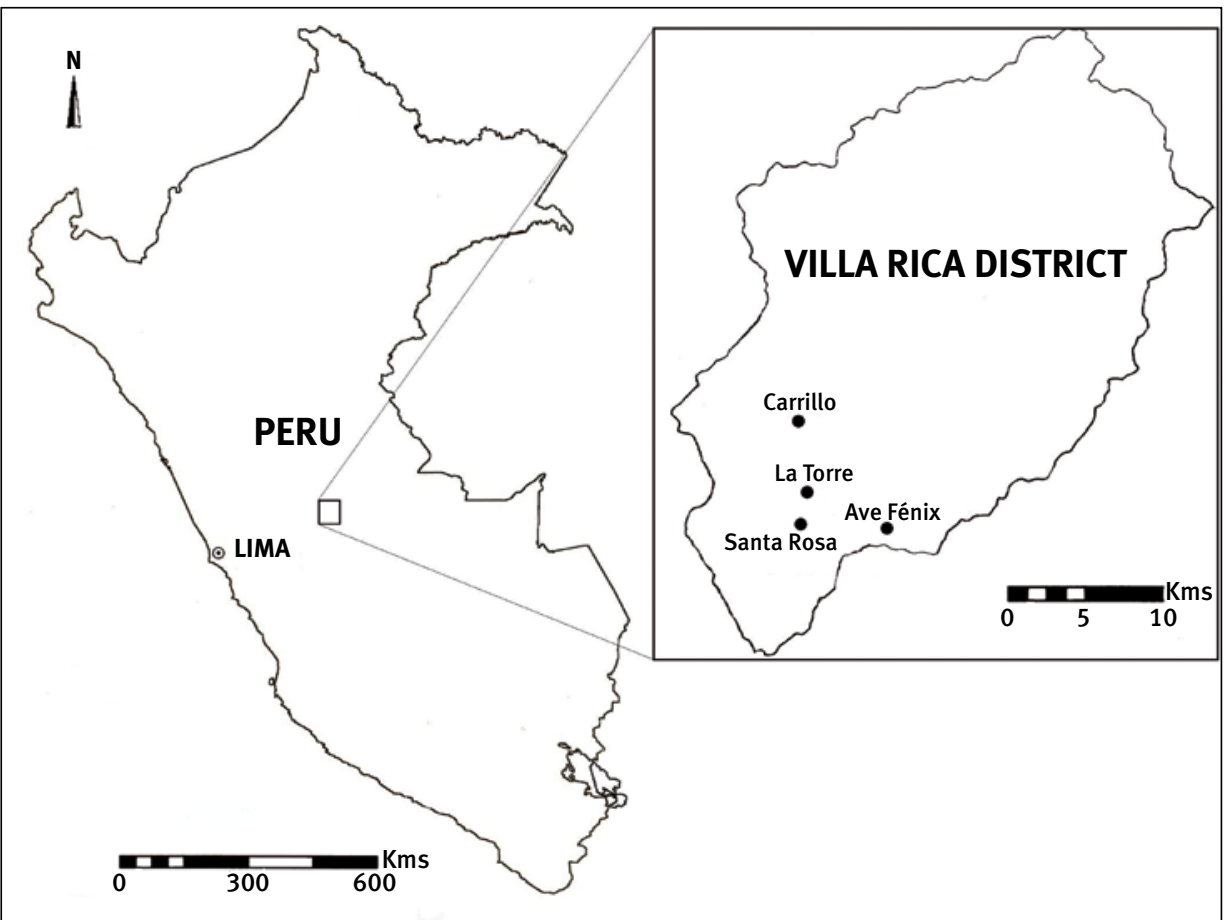
the years 2011-2013 at the shaded site. The average annual air temperature was $18.3 \pm 0.3^{\circ} \mathrm{C}$, and the average annual air humidity was $93.7 \pm 1.4 \%$ over the three measured years (Ehrenbergerová et al., 2017).

\section{Tree measurements and allometric equations}

Diameter at breast height (DBH) and total height of all trees with $\mathrm{DBH} \geq 10 \mathrm{~cm}$ were measured in all studied plantations. The DBH measurements were made in 2012 and then repeated in 2014.

The three most common shade tree species that provide marketable timber were selected for development of models for stem volume prediction: Pinus, Eucalyptus and Retrophyllum. The stem diameter at six different heights of 258 standing trees (89 trees 
Table I.

Basic characteristics of the studied plantations.

\begin{tabular}{|c|c|c|c|c|c|c|c|c|}
\hline \multirow[t]{2}{*}{ Plantation } & \multirow[t]{2}{*}{ Site name } & \multicolumn{2}{|c|}{ Location } & \multirow[t]{2}{*}{ Area } & \multirow[t]{2}{*}{ Altitude } & \multirow{2}{*}{$\begin{array}{c}\text { Shade tree } \\
\text { density }\end{array}$} & \multirow{2}{*}{$\begin{array}{c}\text { Tree } \\
\text { distribution }\end{array}$} & \multirow{2}{*}{$\begin{array}{c}\text { Average } \\
\text { age }\end{array}$} \\
\hline & & $\mathrm{X}$ & $\mathbf{Y}$ & & & & & \\
\hline Ave Fénix & Inga & 475,784 & $8,808,864$ & 7.37 & 1,550 & 176 & random & 15 \\
\hline Santa Rosa & Pinus & 471,531 & $8,809,929$ & 3.98 & 1,540 & 124 & in rows & 15 \\
\hline La Torre & Eucalyptus & 469,052 & $8,811,679$ & 0.85 & 1,530 & 209 & in rows & 11 \\
\hline
\end{tabular}

of Pinus, 110 trees of Eucalyptus and 59 trees of Retrophyllum) was measured in order to calculate stem volume. Applying a non-destructive method, stem diameter at the first three heights $(0.3 \mathrm{~m}, 1.3 \mathrm{~m}$ and $1.8 \mathrm{~m})$ was measured mechanically using callipers, and stem diameter at the other three heights was measured by remote diameter measurement using FieldMap (Jílové u Prahy, Czech Republic) technology (these heights were as follows: half of the distance between the ground and the tree crown, at the base of the tree crown and $10 \mathrm{~cm}$ below the top of the tree). The stem diameters from the six different heights were used to calculate the stem biomass, using FieldMap software which is based on calculation developed by Černý and Pařez (2005).

The stem volume was estimated from the model profile based on the equation of Riemer (Riemer et al., 1995), which is:

$d_{h}=2\left(\frac{i}{1-e^{q(1.3-H)}}+\left(\frac{d_{1.3}}{2}-i\right)\left(1-\frac{1}{1-e^{p(1.3-H)}}\right)+\frac{\left(\frac{d_{1.3}}{2}-i\right) e^{1.3 p}}{1-e^{p(1.3-H)}} e^{-p h}-\frac{i e^{-q H}}{1-e^{q(1.3-H)}} e^{q h}\right)$

where $d_{h}$ is stem diameter at height h, $H$ is the total height of the tree, $d_{1.3}$ is $\mathrm{DBH}$, and $i, p, q$ are model parameters. Specifically, $i$ is the common asymptote for the bottom and top part of the stem, and $p$ characterizes the bottom part and $q$ characterizes the top part of the stem.

To calculate the usable timber volume for trees that were not measured at the six heights, we developed species-specific as well as general allometric equations, where the commercial stem volume was predicted using either $\mathrm{DBH}$ or total height. A visual evaluation of the plotted data suggested that they followed either the power law or Gompertz or logistic functional forms, which were fitted to the data and compared. The formulas used for the models were:

- Power law: $y=a . x^{b}$

- Gompertz: $y=$ a.exp(-b.c $\left.c^{x}\right)$

- Logistic: $y=a /(1+\exp (b-x) / c)$

where $y$ is the usable stem volume, $x$ is the value of the given parameter (DBH or height), and $a, b$ and $c$ are the model coefficients.

The models were created and tested for both the individual species (species-specific models) and for the pooled data (general models). Because there was apparent heteroscedasticity in the majority of the data, we used generalized non-linear models (GNLMs). The best models (species-specific and general) were selected based on the lowest AIC and highest $R^{2}$ values. All analyses were performed in $R$ ( $R$ Core
Team, 2016) using the "nlme" package. Model selection, fitting and evaluation followed the recommended procedures and R script reported by Paine et al. (2012).

Using the equations of the best models, we calculated the commercial timber volume of individual trees and then summed these values for each plantation to obtain the total timber stock per plantation. Species-specific allometric equations were used when possible, but for those for which species-specific models were not available, we calculated timber volume using the general model equation.

It is important for growers to know how many trees they can cut down per year to have a sustainable agroforestry system. To answer this question, we calculated the average annual wood volume increment for each plantation. The annual wood production was calculated as the increase in total timber volume between the dates of the two $\mathrm{DBH}$ measurements divided by the number of years between the

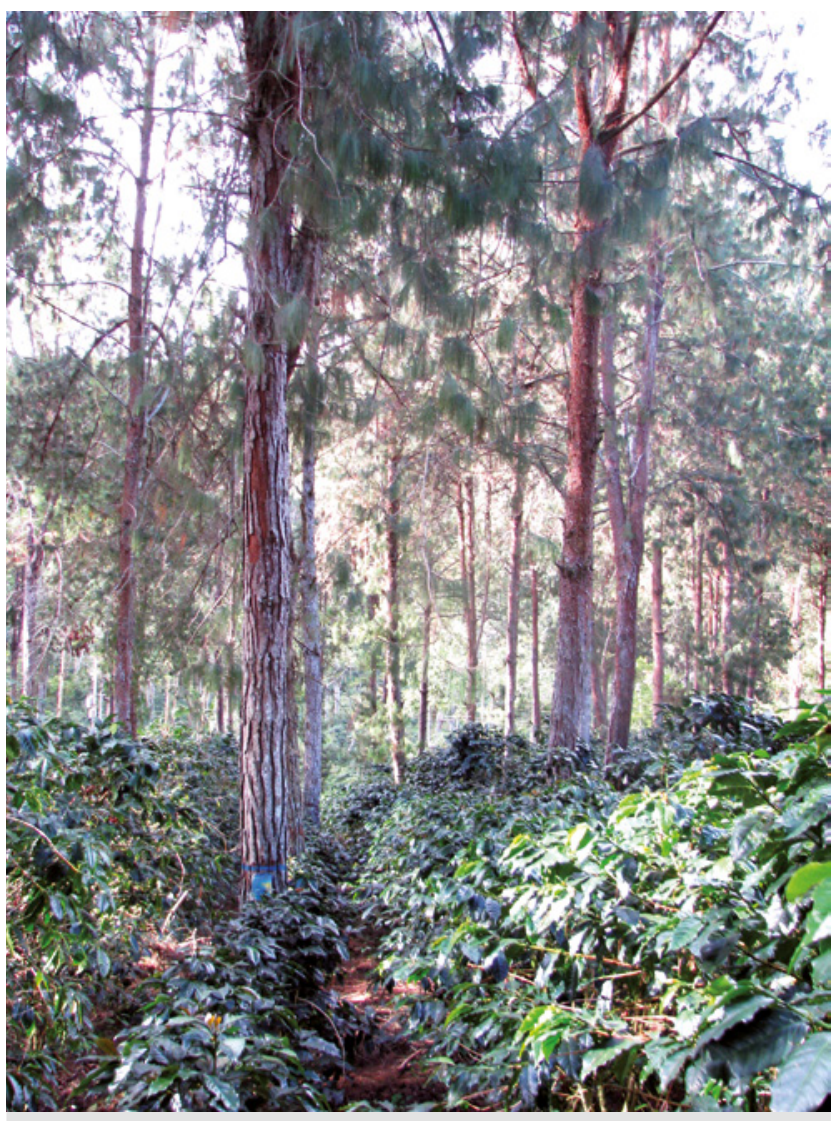

Photo 1.

Santa Rosa plantation where coffee is dominantly shaded by Pinus spp. trees.

Photo L. Ehrenbergerová. 
measurements. To compare the annual increment and wood volume between species, we used linear mixed-effect models with plantation identity used as a random variable. To calculate the total timber value per hectare, the total timber stock per plantation was divided by the plantation area (in hectares) and multiplied by the local timber prices paid to farmers.

\section{Wood and coffee prices}

The shade trees in the studied plantations are used only as a source of timber and firewood, and the non-woody products such as fruits are not sold. To assess the real income that a farmer would receive from selling shade tree timber, we determined the timber prices paid to local farmers by the sawmills nearest to Villa Rica town (table II). The common practice is that farmers sell standing trees to the sawmill, and the sawmill performs the extraction and other wood treatments; therefore, the prices in table II show the real gain realized by the coffee growers. The potential value of the other tree species (including Inga) was calculated using firewood prices. After tree harvesting, new shade trees must be planted on the site. The cost of afforestation in Villa Rica district was 346 USD/ha for mixed plantations of Inga (90\%) and Retrophyllum (10\%) and 338 USD/ha for mixed plantations of

Table III.

Mean characteristics and economic evaluation of individual trees.

\begin{tabular}{|c|c|c|c|c|c|c|}
\hline \multirow[t]{2}{*}{ Species } & \multirow[t]{2}{*}{$\begin{array}{l}\text { Average } \\
\text { diameter }\end{array}$} & \multirow[t]{2}{*}{$\begin{array}{c}\text { Average } \\
\text { high }\end{array}$} & \multirow{2}{*}{$\begin{array}{c}\text { Mean timber } \\
\text { volume } \\
\left(\mathrm{m}^{3} / \text { tree }\right)\end{array}$} & \multirow{2}{*}{$\begin{array}{l}\text { Mean annual } \\
\text { timber increment } \\
\left(\mathrm{dm}^{3} / \text { tree }\right)\end{array}$} & \multicolumn{2}{|c|}{$\begin{array}{l}\text { Mean tree } \\
\text { price (USD) }\end{array}$} \\
\hline & & & & & 2016 & 2018 \\
\hline Eucalyptus spp. & 30.4 & 32.7 & 3.02 & 89.25 & 105.4 & 189.9 \\
\hline Pinus spp. & 35.9 & 21.7 & 0.97 & 57.96 & 33.9 & 61.0 \\
\hline Retrophyllum spp. & 35.4 & 25.5 & 1.02 & 82.24 & 71.2 & 71.2 \\
\hline $\begin{array}{l}\text { Inga spp. } \\
\text { USD: United St }\end{array}$ & $\begin{array}{l}23.1 \\
\text { es doll }\end{array}$ & - & 0.80 & 40.50 & 2.5 & 2.5 \\
\hline
\end{tabular}

Table IV.

Characteristics and economic evaluation of plantations.

\begin{tabular}{|c|c|c|c|c|c|}
\hline Site & $\begin{array}{l}\text { Wood } \\
\text { volume } \\
\left(\mathrm{m}^{3} / \mathrm{ha}\right)\end{array}$ & Year & $\begin{array}{l}\text { Value of } \\
\text { timber } \\
\text { (USD/ha) }\end{array}$ & $\begin{array}{c}\text { Wood volume } \\
\text { increment } \\
\text { ( } \mathrm{m}^{3} / \mathrm{ha} / \text { year) }\end{array}$ & $\begin{array}{l}\text { Value of timber } \\
\text { increment } \\
\text { (USD/ha) }\end{array}$ \\
\hline \multirow[t]{2}{*}{ Inga } & \multirow[t]{2}{*}{50.8} & 2016 & 690 & 1.7 & 30 \\
\hline & & 2018 & 898 & & 39 \\
\hline \multirow[t]{2}{*}{ Pinus } & \multirow[t]{2}{*}{113.1} & 2016 & 12,018 & 10.9 & 693 \\
\hline & & 2018 & 21,404 & & 1,234 \\
\hline \multirow[t]{2}{*}{ Eucalyptus } & \multirow[t]{2}{*}{635.9} & 2016 & 16,621 & 48.1 & 1,526 \\
\hline & & 2018 & 29,474 & & 2,735 \\
\hline
\end{tabular}

Table II.

\begin{tabular}{|c|c|c|c|c|}
\hline \multirow[t]{2}{*}{ Species } & \multirow[t]{2}{*}{ Use } & \multicolumn{2}{|c|}{$\begin{array}{l}\text { Prices of wood } \\
\left.\text { (USD } / \mathrm{m}^{3}\right)\end{array}$} & \multirow{2}{*}{$\begin{array}{l}\text { Prices of } \\
\text { reforestation } \\
\text { (USD/ha) }\end{array}$} \\
\hline & & 2016 & 2018 & \\
\hline Pinus spp. & Timber & 34.9 & 62.9 & 338 \\
\hline Eucalyptus spp. & Timber & 34.9 & 62.9 & 338 \\
\hline Retrophyllum spp. & Timber & 69.8 & 69.8 & 338 \\
\hline Inga spp. & Fuelwood & 3.2 & 3.2 & 346 \\
\hline \multicolumn{5}{|c|}{$\begin{array}{l}\text { Prices are indicated for the cubic meters }\left(\mathrm{m}^{3}\right) \text { of } \\
\text { standing trees. Sources: personal communication } \\
\text { with Ivan La Torre(La Torre plantation, Villa Rica), } \\
\text { Selena Contreras (Santa Rosa plantation, Villa Rica), } \\
\text { Rianne van der Bom (NGO Amazonas, Villa Rica), } \\
\text { Marleni Romero (municipality of Villa Rica). }\end{array}$} \\
\hline
\end{tabular}

Eucalyptus (90\%) and Retrophyllum (10\%) or Pinus (90\%) and Retrophyllum (10\%). All prices were calculated for a spacing of $6 \mathrm{~m} \times 6 \mathrm{~m}$ (278 trees/ha). The costs of reforestation after annual thinning were recalculated based on the number of felled trees.

To compare incomes from shade trees with incomes from coffee yield, we surveyed coffee bean production, relevant selling prices and costs of coffee production. We used the value of coffee yields and prices that were valid for plantations certified by Fair Trade and certified as organic in Villa Rica. The coffee yield was $650 \mathrm{~kg} / \mathrm{ha}$ in 2016 and $550 \mathrm{~kg} / \mathrm{ha}$ in 2018. The price of Fair Trade-certified parchment coffee was 2.32 USD/ $\mathrm{kg}$ in 2016 and $2.38 \mathrm{USD} / \mathrm{kg}$ in 2018. We used the value of production costs of organic coffee certified by Fair Trade in Villa Rica, which was 2,761 USD/ha. This value is comparable to the costs published by JNC (2018). The costs of coffee production were relatively stable and exceeded incomes (see figure 2). For all calculations, we used the exchange rate: 1 USD (United States dollar) $=3.15$ PEN (Peruvian sol).
Timber Prices in Villa Rica Town.

\section{Results}

\section{Timber volume allometric equation}

The best models for timber volume estimation are shown in annex 2 . The models for stem volume estimation using DBH as a predictor were superior to the models with height as a predictor $(\triangle \mathrm{AIC}>22.1)$. Among the models that used DBH, the power law was the best functional form for Retrophyllum and Pinus, whereas a 3-parameter logistic model was the best for Eucalyptus and other species (annex 2). The selected models proved to precisely predict the volume of stem timber $\left(R^{2}>0.9\right)$. 


\section{Economic evaluation}

Eucalyptus trees have the highest mean volume per tree, whereas Pinus and Retrophyllum shade tree species have similar mean volumes per individual tree, i.e., approximately $1 \mathrm{~m}^{3}$. The mean tree volume of Inga was slightly lower (table III). The absolute annual timber increment was highest for Eucalyptus followed by Retrophyllum (table III). Inga had the lowest timber increment (absolute and relative) of all studied species.

The potential income from the sale of shade trees varied greatly between the studied years due to a large difference in wood prices between 2016 and 2018 (table II). The exception was the Inga plantation because Inga wood prices were the same in both studied years but significantly lower than the timber prices for the other tested species. The potential incomes from selling wood from all shade trees represented $31 \%$ at the Inga site, $89 \%$ at the Pinus site and $92 \%$ at the Eucalyptus site of total farm incomes in 2016 (table IV, figure 3) and $41 \%$ at the Inga site, $94 \%$ at the Pinus site $96 \%$ at the Eucalyptus site of total farm incomes in 2018 (table IV, figure 4). The biggest difference between costs (of coffee production and afforestation) and income (from coffee and wood sales) was at the Eucalyptus site, with higher income than costs, followed closely by the Pinus site. On the Inga plantation even after felling all trees, the costs would prevail over income (figure 3 and figure 4).

The potential income from the sale of the wood growth increment was $2 \%$ at the Inga site, $32 \%$ at the Pinus site and $50 \%$ at the Eucalyptus site of total farm income in 2016 (table IV, figure 5) and 3\% at the Inga site, 49\% at the Pinus site and $68 \%$ at the Eucalyptus site of total farm income in 2018 (table IV, figure 6). If we recalculated the annual wood volume increment for the number of individual trees and tree prices paid to growers, we have the following values: Inga site, 2 trees (6 USD/ha); Pinus site, 24 trees (1,481 USD/ha); Eucalyptus site, 16 trees (3,024 USD/ ha) (for simplification, we expected that growers would cut down only the dominant tree species).

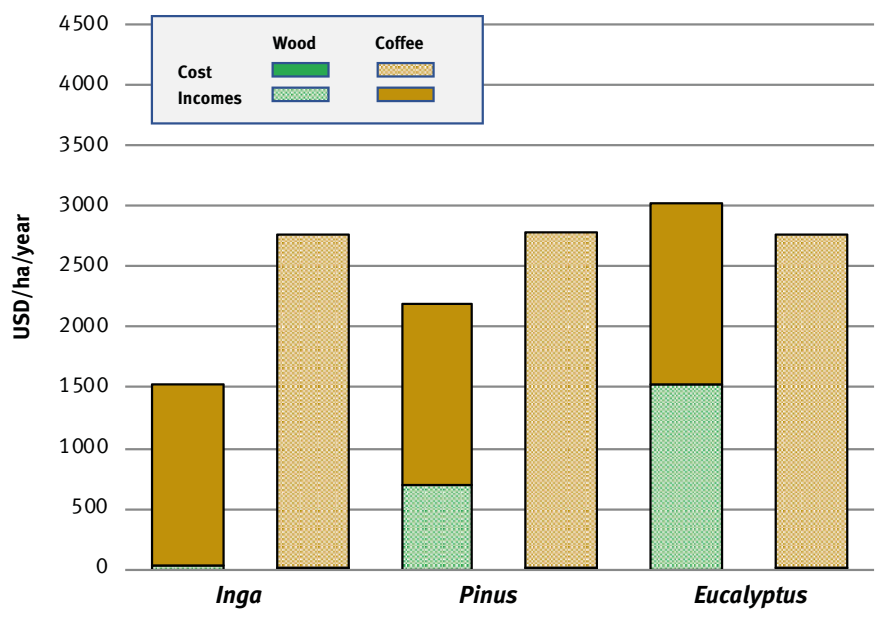

Figure 5.

Annual wood and coffee income and costs per ha in 2016.

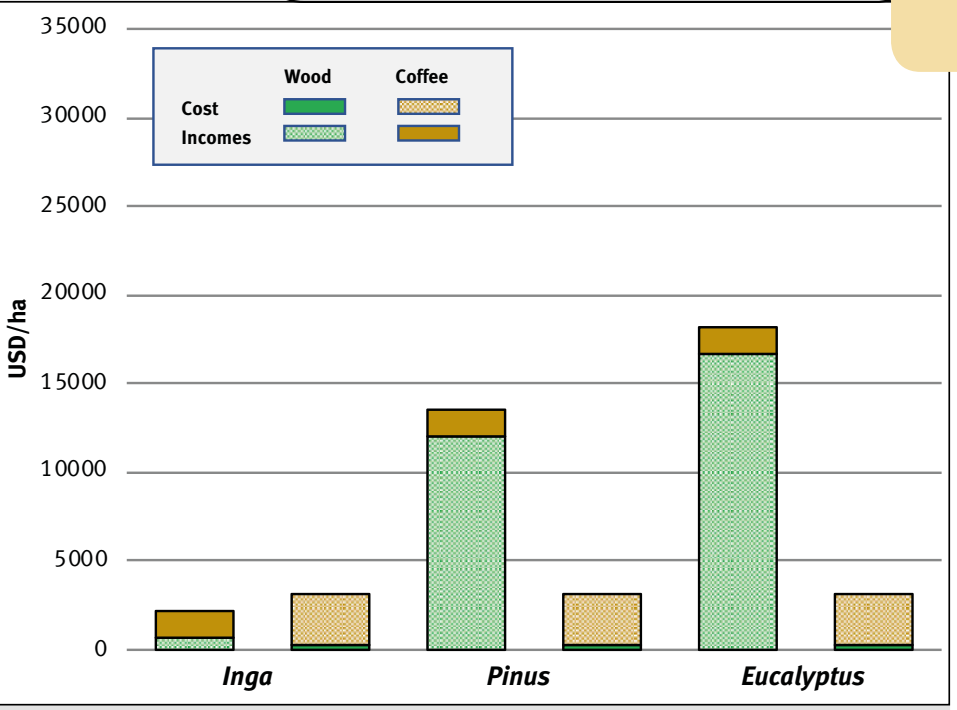

Figure 3.

Total wood and annual coffee income and costs per ha in 2016.

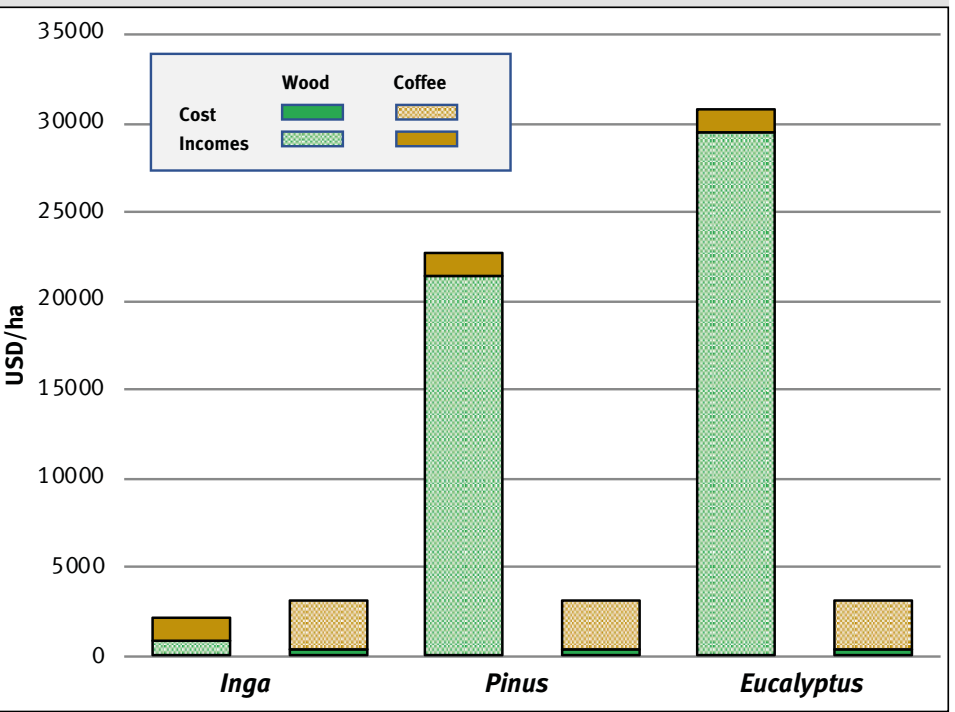

Figure 4.

Total wood and annual coffee income and costs per ha in 2018.

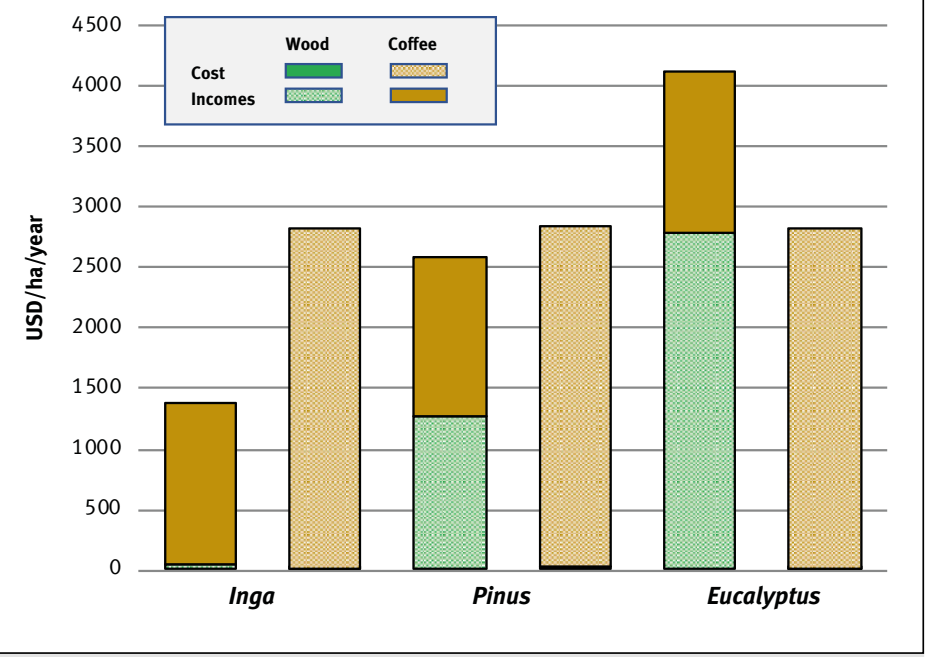

Figure 6.

Annual wood and coffee income and costs per ha in 2018. 


\section{Discussion}

Tree planting density determines timber volume and therefore the commercial value of the shade trees. The relationships between tree density and timber volume found in our study are in line with Hernández et al. (1997), who found that 100 and 300 shade trees of Cordia alliodora in agroforestry coffee plantations contained 132 and $267 \mathrm{~m}^{3} /$ ha of timber. However, Peeters et al. (2003) reported that coffee plantations dominated by Inga spp. with 176 trees/ha only contained $2.7 \pm 1.69 \mathrm{~m}^{3} /$ ha of timber, which is much less than the Inga site in our study. Peeters et al. (2003) also reported that traditional plantations formed by clearing the understory and some of the tropical forest trees with 277 trees/ha contained $29 \pm 7.90 \mathrm{~m}^{3} /$ ha of timber, which is still less than the amount we found in our study. Unfortunately, we did not find a relationship between tree density and wood volume for Eucalyptus or Pinus trees in agroforestry systems.

We developed models for stem volume prediction for selected shade tree species (Pinus, Eucalyptus, Retrophyllum) and one general model for other shade tree species. These models will allow agroforestry growers to easily determine the quantity of timber or fuelwood on their

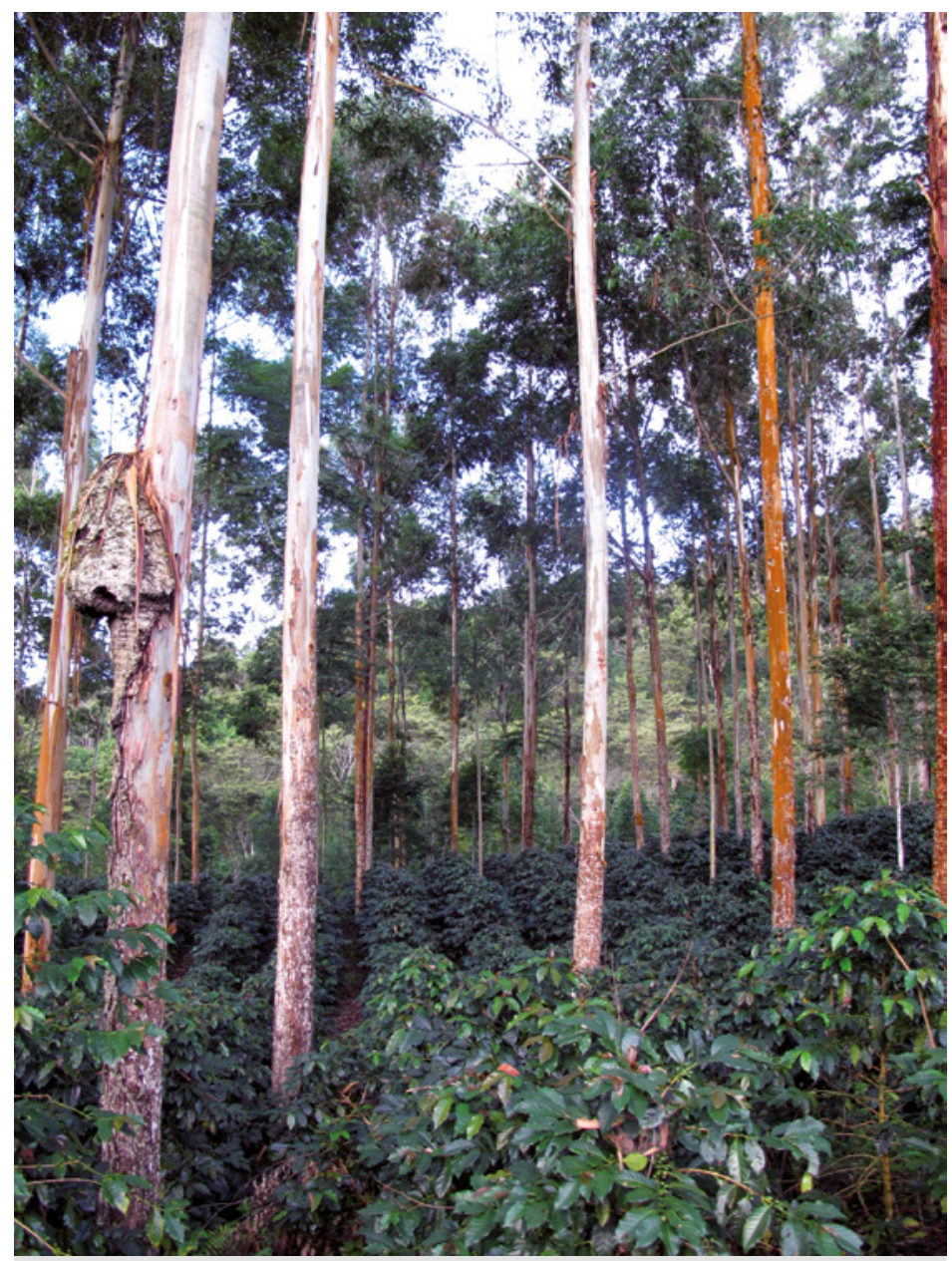

Photo 3.

La Torre coffee plantation (Eucalyptus site) shaded by 11 years old Eucalyptus spp. trees.

Photo L. Ehrenbergerová. plantations from the height and the $\mathrm{DBH}$ of the trees. It would be a good idea to put these equations into a phone application so that growers can determine the timber volume directly in the field without complicated calculations.

There are various motivations for growers to change monoculture coffee plantations to agroforestry systems, and the vision of economic benefits is one of them. A steep increase in production costs was observed in major Latin American coffee-producing countries in recent years (ICO, 2016), linked to increasing labour costs and rising prices of agrochemical inputs (Jezeer et al., 2018). We situated our research in the years 2016 and 2018, when the income from coffee was lower than the costs of coffee production in the Villa Rica district, to discover whether the income from wood could help to improve the financial situation of coffee growers. Our study demonstrated that the contribution of wood production from the sale of shade trees to the total income of coffee farms may vary greatly. First, we calculated the potential income that coffee growers could gain if they cut all shade trees and sold them. In this case, the farmers of the Eucalyptus and Pinus sites could have a high income even after the deduction of afforestation costs. However, the costs of coffee production outweigh the income in the long term, and if the farmers remove all the shade trees, they will have no additional income from agroforestry for a decade. Moreover, the benefits of agroforestry systems, such as the stabilization of microclimatic conditions (Lin, 2007; Siles et al., 2010), soil protection (Wintgens, 2004), carbon fixation (Soto-Pinto et al., 2010; Ehrenbergerová et al., 2016) or providing refuge for forest biota (Perfecto et al., 1996; Moguel and Toledo, 1999), will be lost for many years.

In a study by Jezeer et al. (2018), conducted in agroforestry coffee plantations in the department of San Martin, Peru, net income was highly variable, with an average income of $1,047 \pm 949 € / \mathrm{ha} / \mathrm{y}$, ranging from 1,480 to $4,303 € /$ ha/y. Rice (2008) found that, between 1999 and 2003 in southern Peru, $28.5 \pm 1.87 \%$ of the total income of coffee plantations came from shade-derived sources. However, the plantations studied by Rice (2008) and shaded by native species had income not only from timber (5\% of shade-derived income (SDI) - self consumption; $1 \%$ SDI - sale) and fuelwood (35\% SDI - self consumption) but also from the sale of fruits ( $42 \% \mathrm{SDI}$ - self consumption; $3 \%$ SDI - sale) and animals (12\% SDI - self consumption; $2 \%$ - sale). The potential annual income from the sale of wood at the Inga site, where the predominant use of shade trees is as a fuelwood, was very low (2\% in 2015 and $3 \%$ in 2018), and total coffee farm costs were higher than income. However, the potential annual income from the sale of wood and coffee at the Pinus site was already close to the total plantation costs, and at the Eucalyptus site, the potential annual income was even higher. The calculation of potential annual increments allowed us to estimate how many trees can be felled annually. In the annual felling of selected shade trees in accordance with the annual wood increment, we see the potential for agroforestry to improve the economic situation of coffee growers in a sustainable way. 
Shade trees provide environmental and socioeconomic benefits to growers (Rice, 2008), as stated above. However, our study demonstrated that exotic shade tree species such as Eucalyptus and Pinus have higher economic value than Inga trees, which are native and likely to be more beneficial for local ecosystems. An interesting finding was that Retrophyllum (a species native to Peru) had a high timber value and a large timber supply, making it a shade tree species with high potential for agroforestry. Currently, Retrophyllum is grown as a boundary tree, and it is necessary to study how it would affect coffee production if it were planted at a higher density.

In conclusion, it should be said that agroforestry shaded by Inga and other native trees, which brings already mentioned environmental benefits compared to the cultivation of exotic shade trees, does not provide growers with high income from wood. For this reason, financial motivation and support for agroforestry plantations to use native shade tree species and thus promote environmental benefits is needed. It is necessary to develop a suitable method of support that will be simple for farmers. It is also important to search for other native trees that have fast growth and high wood value and that are suitable to provide shade for coffee. These shade trees can both provide a high income and have positive effects on the ecosystem.

\section{Conclusion}

Our study demonstrated that the plantation shaded predominantly by exotic Eucalyptus trees had the highest potential annual and total timber value, followed by the plantation predominantly shaded by Pinus. The potential annual income from the sale of wood at the Inga site, where the predominant use of shade trees is as a fuelwood, was very low, and total coffee farm costs were higher than income even if we calculated that the farmers would cut all the trees. However, the native and relatively rare Retrophyllum shade trees had comparable timber values with Pinus and Eucalyptus trees, which makes Retrophyllum a tree species with high potential for coffee agroforestry systems. Further research should focus on finding native species that are suitable for coffee shading, with fast growth and high timber value, that can both provide a high income and have positive effects on the ecosystem.

\section{Acknowledgements}

The authors are grateful to the Marín, Carrillo and La Torre families and Ms. Selena Contreras for their help and for letting us conduct this study on their plantations. We are also thankful for Jorge Mattos Olavarria, director of MapGeosolution, who provided the FieldMap technology. This work was supported by the POPRAR project [CZ.1.07/2.2.00/28.0303] and The active involvement of Czech scientists in international research activities of the IALE International Association for Landscape Ecology [LG15034].

\section{Annex 1.}

\section{Description of studied coffee plantations.}

The Inga site was located in Alto Palomar, near Villa Rica town. This site represented the typical management of agroforestry plantations in Villa Rica District. It was dominantly shaded by Inga spp. (Inga adenophylla, I. densiflora, I. edulis, I. feuillei, I. velutina). The Inga trees were used as firewood. The Inga site had the greatest diversity of shade trees, and among other species, we found Retrophyllum rospigliosii, Acrocarpus fraxinifolius Arn., Albizia sp., Aniba muca Mez, Boehmeria sp., Cabralea canjerana (Vell.) Cecropia sp., Cedrela odorata L., Ceiba pentandra (L.) Gaertn., Cordia alliodora (Ruiz \& Pav.) Oken, Croton draconoides Müll. Arg., Cupressus sp., Erythrina edulis Triana ex Micheli, Eucalyptus saligna Sm., Juglans neotropica Diels, Miconia dipsacea Naudin, Persea americana Miller, Pinus radiata D. Don, $P$. tecunumanii Eguiluz \& J.P. Perry. The shade trees were randomly distributed on the plantation, and their main role was to shade the coffee plants. For this reason, the trees were planted at a low density. At the Inga site, we identified the following coffee varieties: Typica, Catimor, Caturra and Catuay. The field had rough, broken topography with an average slope angle of $18.2^{\circ}$.

The Pinus site was located in Oconal, $4 \mathrm{~km}$ south of Villa Rica town. The average slope angle was $16.4^{\circ}$. The dominant shade species were $P$. oocarpa and $P$. tecunumanii. Among other shade tree species, we found Retrophyllum rospigliosii, Acrocarpus fraxinifolius, Eucalyptus spp., and Inga spp. The shade trees were planted in the rows. Shade trees were planted not only to shade the coffee but also for the sale of timber. The following coffee varieties were present on the site: Typica, Catimor and Caturra.

The Eucalyptus site was located next to Lake Oconal, and the average slope angle was $15.8^{\circ}$. This site was shaded mainly by Eucalyptus (E. saligna and E. grandis). Other shade tree species found there were Schizolobium amazonicum Huber, Calycophyllum spruceanum (Ben.) Hook F. and Swietenia macrophylla $\mathrm{G}$. King. These tree species were very young and therefore were not measured (diameter at breast height $<10 \mathrm{~cm}$ ). The shaded trees were planted in the rows, and timber production was the priority for the owner. The following coffee varieties were present on the sites: Typica, Catimor and Caturra.

\section{Annex 2.}

The best models for stem volume prediction for selected shade tree species and a general model for all other species.

\begin{tabular}{|l|l|c|c|c|c|}
\hline Species & Model & \multicolumn{3}{c|}{ Model coefficients } & $\mathbf{R}^{2}$ \\
& & $\mathbf{a}$ & $\mathbf{b}$ & $\mathbf{C}$ & \\
Eucalyptus & Logistic & 6.13 & 517.76 & 102.85 & 0.92 \\
\hline Pinus & Power law & $1.53 \mathrm{E}-07$ & 0.08 & - & 0.95 \\
\hline Retrophyllum & Power law & $3.97 \mathrm{E}-07$ & 0.05 & - & 0.97 \\
\hline Others & Logistic & 6.40 & 550.09 & 107.49 & 0.91 \\
\hline
\end{tabular}




\section{References}

Alavalapati J. R. R., Nair P. K., 2001. Socioeconomic and institutional perspectives of agroforestry. In: Palo M., Uusivuori J. (eds). World Forests, Society, and Environment - Markets and Policies. Dordrecht, The Netherlands, Kluwer Academic Publishers, 71-81. https://doi.org/10.1007/97894-010-0664-4 5

Avelino J., Cristancho M., Georgiou S., Imbach P., Aguilar L., Bornemann G., et al., 2015. The coffee rust crises in Colombia and Central America (2008-2013): impacts, plausible causes and proposed solutions. Food Security, 7: 303-321. https:// doi.org/10.1007/s12571-015-0446-9

Barham B. L., Weber J. J., 2012. The economic sustainability of certified coffee: Recent evidence from Mexico and Peru. World Development, 40: 1269-1279. https://doi. org/10.1016/i.worlddev.2011.11.005

Barradas V. L., Fanjul L., 1984. La importancia de la cobertura arbórea en la temperatura del agroecosistema cafetalero. Biótica, 9 (4): 415-421.

Beer J., 1987. Advantages, disadvantages and desirable characteristics of shade trees for coffee, cacao and tea. Agroforestry Systems, 5: 3-13.

Brack E. A., Mendiola Vargas C., 2012. Ecología del Perú. Lima, Perú, Bruño, 495 p. https://www.peruecologico.com. pe/libro.htm

Černý M., Pařez J., 2005. Zjišt'ování objemu a sortimentace stojících stromů s využitím modelu tvaru kmene. Lesnická Práce, 12 (84): 22-25.

Chave J., Andalo C., Brown S., Cairns M. A., Chambers J. Q., Eamus D., et al., 2005. Tree allometry and improved estimation of carbon stocks and balance in tropical forests. Ecologia, 145: 87-99. https://doi.org/10.1007/s00442005-0100-x

Cuadras S., 2006. Perú un país de cafés de altura, [online] Fórum Café. http://www.forumdelcafe.com/pdf/F 07-Peru. pdf

Daviron B., Ponte S., 2005. The coffee paradox: Commodity trade and the elusive promise of development. London, United Kingdom, Zed Books, 320 p.

Díaz Vargas C., Willems M. C., 2017. Línea de Base del Sector Café en el Perú - Documento de trabajo. Programa de las Naciones Unidas para el Desarrollo (PNUD), 58 p. https:// doi.org/10.21678/apuntes.39.450

Ehrenbergerová L., Cienciala E., Kučera A., Guy L., Habrová H., 2016. Carbon stock in agroforestry coffee plantations with different shade trees in Villa Rica, Peru. Agroforestry Systems, 90: 433-445. https://doi.org/10.1007/s10457-015-9865-z Ehrenbergerová L., Šenfeldr M., Habrová H., 2017. Impact of tree shading on the microclimate of a coffee plantation: a case study from the Peruvian Amazon. Bois et Forêts des Tropiques, 334 (4): 13-22. https://doi.org/10.19182/ bft2017.334.a31488

Garrett H. E., Rietveld W. J., Fisher R. F. (eds), 2000. North American Agroforestry: An Integrated Science and Practice. Madison, WI, USA, American Society of Agronomy, Inc.

Greenberg R., Rice R. A., 1999. Manual de café bajo sombra y biodiversidad en el Perú. Centro de Aves Migratorias, Smitsonian Institute, $52 \mathrm{p}$.
Hernández O. G., Beer J., Henning von Platen, 1997. Rendimiento de café (Coffea arabica cv Caturra), producción de madera (Cordia alliodora) y análisis financiero de plantaciones con diferentes densidades de sombra en Costa Rica. Agroforestería en las Americas, 13 (4): 8-13.

Horowitz C., 2016. Paris Agreement. International Legal Materials, 55 (4): 740-755.

ICO (International Coffee Organization), 2003. Impact of the coffee crisis on poverty in producing countries. London, United Kingdom, ICO, 10 p. http://www.ico.org/documents/ icc89-5r1e.pdf

ICO (International Coffee Organization), 2016. Historical Data on the Global Coffee Trade. ICO, website database. https://doi.org/10.1016/j.agrformet.2006.12.009

Jezeer R. E., Santos M. J., Boot R. G. A., et al., 2018. Effects of shade and input management on economic performance of small-scale Peruvian coffee systems. Agricultural Systems, 162: 179-190. https://doi.org/10.1016/j. agsy.2018.01.014

Jiménez-Avila E., Martınez V. P., 1979. Estudios ecológicos del agroecosistema cafetalero. II. Producción de materia orgánica en diferentes tipos de estructura. Biótica, 4: 109126.

JNC (Junta Nacional del Café), 2018. Evolución de la producción de café en el Peru (1999-2012). Junta Nacional del Café, sitio web. https://doi.org/10.2307/i. ctv47w55p.20

Lin B. B., 2007. Agroforestry management as an adaptive strategy against potential microclimate extremes in coffee agriculture. Agricultural and Forest Meteorology, 144: 85-94. https://doi.org/10.1016/j.agrformet.2006.12.009

Michéli E., Schad P., Spaargaren O., Dent D., Nachtergale F., 2006. World reference base for soil resources 2006 A framework for international classification, correlation and communication. Rome, Italy, Food and Agricultural Organization of the United Nations, Report 103, 145 p. http://www.fao.org/3/a-a0510e.pdf

Méndez J. M., Pantigoso P., Paredes J., Bellina J. C., 2015. Guía de Negocios e Inversión en el Perú 2014/2015. EY Perú, Ministerio de Relaciones Exteriores. http://www.rree. gob.pe/promocioneconomica/invierta/Documents/Guia de Negocios e Inversion en el Peru 2014 2015.pdf

Ministerio de Agricultura y Riego, 2017. Plan Nacional de Cultivos (Campaña Agrícola 2018-2019) 2017. El Ministerio de Agricultura y Riego (MINAGRI), 293 p. https:// www.agromoquegua.gob.pe/doc/PLAN NACIONAL DE CULTIVOS 2018-2019.pdf

Moguel P., Toledo V. M., 1999. Biodiversity conservation in traditional coffee systems of Mexico. Conservation Biology, 13: 11-21. https://doi.org/10.1046/i.15231739.1999.97153.x

Morton J. F., 2007. The impact of climate change on smallholder and subsistence agriculture. PNAS, 104: 1968019685. http://dx.doi.org/10.1073/pnas.0701855104

Nair P. K. R., 2002. Our Fragile World: Challenges and Opportunities for Sustainable Development. Forerunner to the Encyclopedia of Life Support Systems (M. K. Tolba, Editor), Vols I and II. Agroforestry Systems, 54 (3): 251. https://doi.org/10.1023/A:1016002827733

Nair P. K. R., 1993. An Introduction to Agroforestry. Dordrecht, The Netherlands, Kluwer Academic Publishers, 499 p. 
Nelson V., Haggar J., Martin A., Donovan J., Borasino E., Hasyim W., et al., 2016. Fairtrade Coffee: A Study to Assess the Impact of Fairtrade for Coffee Smallholders and Producer Organisations in Indonesia, Mexico, Peru and Tanzania. Chatham, United Kingdom, Natural Resources Institute, University of Greenwich, 187 p. https://www. maxhavelaar.ch/fileadmin/CH/Was ist Fairtrade / Wirkungsstudien/2016 NRI Coffee Impact Assessment. pdf

Noponen M. R., Haggar J. P., Edwards-Jones G., Healey J. R., 2013. Intensification of coffee systems can increase the effectiveness of REDD mechanisms. Agricultural Systems, 119: 1-9. https://doi.org/10.1016/i.agsy.2013.03.006

Paine C. E. T., Marthews T. R., Vogt D. R., Purves D., Rees M., Hector A., et al., 2012. How to fit nonlinear plant growth models and calculate growth rates: an update for ecologists. Methods in Ecology and Evolution, 3: 245-256. https://doi. org/10.1111/j.2041-210x.2011.00155.x

Peeters L. Y. K., Soto-Pinto L., Perales H., Montoya G., Ishiki M., 2003. Coffee production, timber, and firewood in traditional and Inga-shaded plantations in Southern Mexico. Agriculture, Ecosystems \& Environment, 95: 481-493. https://doi.org/10.1016/s0167-8809(02)00204-9

Perfecto I., Rice R. A., Greenberg R., Van der Voort M. E., 1996. Shade Coffee: Disappearing Refuge for Biodiversity. Bioscience, 46: 596-608. https://doi. org/10.2307/1312989

Ponce Gonzáles M. A., 2008. Plan de Desarollo Concentrado: distrito de Villa Rica 2009-2018. Lima, Perú, Desco, Centro de Estudios y Promoción del Desarrollo, Programa Selva Central, 24 p. http://www.desco.org.pe/recursos/site/ files/969/PDC VRica.pdf

R Core Team, 2016. R: A Language and Environment for Statistical Computing. Vienna, Austria, R Foundation for Statistical Computing. https://www.R-project.org/

Rice R. A., 2008. Agricultural intensification within agroforestry: The case of coffee and wood products. Agriculture, Ecosystems \& Environment, 128: 212-218. https://doi.org/10.1016/i.agee.2008.06.007

Riemer T., Gadow K. V., Sloboda B., 1995. Ein Modell zur Beschreibung von Baumschaften. Allgemeine Forst- und Jagdzeitung, 166 (7): 144-147.

Scherr S. J., 2004. Building opportunities for small-farm agroforestry to supply domestic wood markets in developing countries. Agroforestry Systems, 61: 357-370. https://doi. org/10.1023/b:agfo.0000029010.97567.2b

Schroth G., da Fonseca G. A. B., Harvey C. A., Gascon C., Vasconcelos H. L., Izac A.-M. N., 2004. Agroforestry and Biodiversity Conservation in Tropical Landscapes. Washington, DC, USA, Island Press, 537 p. http:// library.uniteddiversity.coop/Permaculture/Agroforestry/ Agroforestry and Biodiversity Conservation in Tropical Landscapes.pdf

Siles P., Vaast P., Dreyer E., Harmand J., 2010. Rainfall partitioning into throughfall, stemflow and interception loss in a coffee (Coffea arabica L.) monoculture compared to an agroforestry system with Inga densiflora. Journal of Hydrology, 395: 39-48. https://doi.org/10.1016/i. jhydrol.2010.10.005

Soto-Pinto L., Anzueto M., Mendoza J., Ferrer G. J., Jong B., 2010. Carbon sequestration through agroforestry in indigenous communities of Chiapas, Mexico. Agroforestry

Systems, 78: 39-51. https://doi.org/10.1007/s10457-0099247-5

Steffan-Dewenter I., Kessler M., Barkmann J., Bos M. M., Buchori D., Erasmi S., etal., 2007. Trade-offs between income, biodiversity, and ecosystem functioning during tropical rainforest conversion and agroforestry intensification. Proceedings of the National Academy of Sciences, 104: 4973-4978. https://doi.org/10.1073/pnas.0608409104

Wintgens J. N., 2004. Coffee: Growing, Processing, Sustainable Production: A Guidebook for Growers, Processors, Traders, and Researchers. Weinheim, Germany, Wiley-VCH Verlag GmbH \& Co. KGaA, 980 p. https://doi. org/10.1002/9783527619627

\section{Ehrenbergerová et al. - Author’s contributions}

CONTRIBUTOR ROLE

Conceptualization

\begin{tabular}{l} 
Data Curation \\
\hline Formal Analysis \\
\hline Funding Acquisition
\end{tabular}

Investigation

Methodology

Project Administration

Resources
Supervision

Validation

Visualization

Writing - Original Draft

Preparation

Writing - Review

\& Editing 